\title{
Beta cell antigens in type I diabetes: triggers in pathogenesis and therapeutic targets
}

\author{
Anna Moser ${ }^{1,2}$, Hsiang-Ting $\mathrm{Hsu}^{1,2}$ and Peter van Endert ${ }^{1,2 *}$
}

Addresses: ${ }^{1}$ Faculté de Médecine René Descartes, Université Paris Descartes, 161 rue de Sèvres, 75015 Paris, France; ${ }^{2}$ Institut National de la Santé et de la Recherche Médicale, Unité 1013, 161 rue de Sèvres, 75015 Paris, France

*Corresponding author: Peter van Endert (peter.van-endert@inserm.fr)

Fl000 Biology Reports 2010, 2:75 (doi:10.34I0/B2-75)

This is an open-access article distributed under the terms of the Creative Commons Attribution-Non Commercial License (http://creativecommons.org/licenses/by-nc/3.0/legalcode), which permits unrestricted use, distribution, and reproduction in any medium, provided the original work is properly cited. You may not use this work for commercial purposes.

The electronic version of this article is the complete one and can be found at: http://f1000.com/reports/b/2/75

\begin{abstract}
Recognition of pancreatic beta cell antigens by autoreactive T lymphocytes plays a central role in the pathogenesis of insulin-dependent type I diabetes. Recent results suggest that non-conventional antigenic epitope processing and presentation may contribute to triggering and maintaining autoreactive responses. Moreover, promising results raise hope that autoantigens may become safe and specific therapeutics for type I diabetes in the future.
\end{abstract}

\section{Introduction and context}

Ample evidence documents that both $\mathrm{CD} 4^{+}$helper and $\mathrm{CD} 8^{+}$killer $\mathrm{T}$ lymphocytes are critical in the pathogenesis of autoimmune type 1 diabetes (T1D) [1]. Although the initial events triggering autoreactive responses remain unclear, specific autoantigen presentation by strongly disease-associated major histocompatibility complex (MHC) class II molecules and, according to recent results, weakly disease-associated MHC class I molecules is thought to favor priming and expansion of pathogenic $\mathrm{T}$ cells [2]. Among the steadily expanding list of autoantigens, many are shared between patients and non-obese diabetic (NOD) mice, the murine model of the disease. In patients, autoantibodies recognizing four antigens insulin, glutamic acid decarboxylase (GAD), insulinoma antigen-2, and the recently discovered ZnT8 - have strong disease-predictive value and are measured in clinical routine diagnostics [3]. Other autoantigens such as isletspecific glucose-6-phosphate catalytic subunit-related protein (IGRP) and the very recently identified chromogranin A [4] have been studied mainly or exclusively in mice. The critical issue of whether there is one autoantigen whose recognition by $\mathrm{T}$ cells is an obligatory triggering event at the onset of the autoimmune response has been much discussed. In the NOD model, recent evidence suggests that insulin is one such primary triggering antigen [5]. Mice tolerized to insulin [6] or mice expressing exclusively an insulin molecule lacking the immunodominant T-cell epitopes recognized by $\mathrm{CD} 4^{+}$and $\mathrm{CD} 8^{+} \mathrm{T}$ cells [7] develop neither diabetes nor insulitis, whereas similar tolerization to other autoantigens has no such effect $[8,9]$. It remains unclear whether insulin or any other antigen plays a similar role in humans.

The pivotal role of T cells in T1D has prompted sustained and ongoing efforts to identify autoantigenic epitopes, which can be used to develop T-cell assays potentially useful for disease prediction or monitoring of immunotherapeutic intervention (or both). We [10] and others [11] have identified a large number of mainly HLA-A2 restricted autoantigenic $\mathrm{CD}^{+}{ }^{+} \mathrm{T}$-cell epitopes. Using these epitopes, we could develop an enzyme-linked immunosorbent spot (ELISpot) T-cell assay that detected interferon-gamma-secreting $\mathrm{T}$ cells in the vast majority of patients at disease onset, whereas recognition seemed to vanish during longer-standing disease $[12,13]$. Recent studies have identified a number of epitopes derived from the proinsulin signal peptide, whose level of presentation may be proportional to the secretory activity of beta cells $[14,15]$. However, a recent blinded study evaluating CD $4^{+}$ 
T-cell assays found that the sensitivity and specificity of ELISpot and proliferation assays using purified antigens or epitopes did not exceed $61 \%$ and $69 \%$, respectively, a performance greatly inferior to autoantibody assays [16]. Moreover, despite much effort spent on T-cell assays, studies showing that T-cell assays are actually useful for predicting or monitoring intervention have not been published as of yet.

\section{Major recent advances \\ What renders an islet cell protein autoantigenic and potentially pathogenic?}

Among the vast number of proteins expressed by beta cells, only a few are prominent targets of the cellular autoimmune response, but the reasons for this selectivity have remained mysterious. One fairly constant but unexplained feature of prominent autoantigens is their association with secretory granules. Recent findings provide intriguing new leads with respect to this issue. The BDC2.5 CD4 ${ }^{+}$ $\mathrm{T}$-cell clone and $\mathrm{T}$-cell receptor-transgenic mouse line, used in numerous studies, recognize the most recently described autoantigen, chromogranin A, another secretory granule protein [4]. Interestingly, the peptide recognized by these cells interacts with only the C-terminal half of the I-Ag7 peptide-binding site together with a flanking sequence. This suggests a non-conventional interaction with the T cell in a manner reminiscent of immunodominant $\mathrm{CD} 4^{+} \mathrm{T}$ cells involved in a mouse model of multiple sclerosis [17]. Non-conventional peptide-MHC class II complexes were also shown to play an important role in the recognition of the critical insulin epitope B9-23 by pathogenic T cells. Mohan and colleagues [18] found that many isletinfiltrating $\mathrm{T}$ cells recognizing this epitope are of 'type $\mathrm{B}^{\text {'; }}$ that is, these cells recognize complexes formed by incubation of antigen-presenting cells with the cognate peptide but not those formed by incubation with the source protein insulin, the latter being recognized only by 'type A' T cells. The molecular mechanism for formation of type B complexes is unclear, but Mohan et al. [18] suggest that extremely high antigen concentration, a hallmark of insulin in islets, together with the absence of type $\mathrm{B}$ complexes during thymic selection, plays a crucial role in the emergence and stimulation of type B insulin-specific $T$ cells. A specific antigen-processing event could account for the fact that type B complexes may be produced only in islets. The notion that a specific potentially novel antigenprocessing pathway may play a role in conferring dominant autoantigen status to insulin is supported by another study. Brosi et al. [19] showed that the priming of diabetogenic insulin-specific $\mathrm{CD}^{+} \mathrm{T}$ cells upon DNA vaccination in mice that express the co-stimulatory molecule CD80 in islets depends on translocation of the vaccine-encoded antigen into the endoplasmic reticulum. Although the underlying mechanism is entirely unclear, this together with the other cited studies raises the possibility that specific antigen-processing and presentation pathways and events play a role in the autoantigenicity of insulin and possibly other autoantigens.

\section{Autoantigens as therapeutics}

Although immunomodulation through CD3-specific antibodies remains the most successful biological therapeutic for T1D [20,21], the biological risk necessarily associated with similar strategies has prompted efforts to develop therapeutic strategies based on autoantigens, which are expected to be more specific and safer. In the NOD model, it is well established that treatment of prediabetic mice with various autoantigens prevents disease [22]. After a number of unsuccessful trials using insulin in humans, a recent study demonstrated for the first time a beneficial effect of autoantigen administration to patients at disease onset [23]. Injection of $20 \mu \mathrm{g}$ of GAD in alum resulted in a slower decline of glucose-stimulated C-peptide levels in patients treated no later than 6 months after diagnosis. In these patients (unlike in anti-CD3-treated patients [21]), no reduction in insulin needs was observed, but this result encourages further development of autoantigen-based approaches in humans.

A promising novel strategy for the reversal of autoimmunity was very recently described in an elegant study by Tsai and colleagues [24]. These authors found that NOD mice harbor antigen-experienced $\mathrm{CD}^{+} \mathrm{T}$ cells recognizing the highly immunodominant autoantigen IGRP, which can be expanded by immunization with nanoparticles coated with specific peptide-MHC complexes. The expanded cells act as suppressors that prevent disease in young mice and, remarkably, reverse disease in overtly diabetic mice, a feat previously unmatched for antigen-based therapies. Nanoparticle stimulation of relatively minor T-cell populations also induced the generation of protective suppressor cells, suggesting that the application of the strategy does not require prior identification of immunodominant T-cell populations in every patient treated.

\section{Future directions}

As so often is the case, these intriguing studies leave more questions open than they answer. With respect to the parameters determining autoantigenicity, the general validity of the observed phenomena needs to be studied. Is partial filling of the MHC class II peptide-binding site a common feature of autoantigenic CD4 ${ }^{+} \mathrm{T}$-cell epitopes? Can 'type $\mathrm{B}^{\prime}$ T cells with specificity for autoantigens other than insulin be found? Given that transferred preprocessed epitopes are considered highly unstable and 
prone to degradation (at least in the context of MHC class I cross-presentation), how does insulin peptide B9-23 produced in beta cells 'survive' to be presented by MHC class II molecules of professional antigenpresenting cells? Why does proinsulin targeting to the endoplasmic reticulum increase the priming of pathogenic insulin-specific $\mathrm{CD} 8^{+} \mathrm{T}$ cells?

With regard to therapeutic approaches, the efficacy must be ameliorated greatly if true therapeutic benefits are to be obtained in patients. Combination with low-dose immunomodulatory treatments and/or earlier treatment of patients with relatively high C-peptide levels could be roads to follow. T-cell assays with better performance or novel T-cell assays likely will be required before clinical use can be envisaged. Finally, T-cell assays should be used to monitor patients at T1D risk and/or patients undergoing immunotherapy to prove the clinical interest of these assays.

\section{Abbreviations}

ELISpot, enzyme-linked immunosorbent spot; GAD, glutamic acid decarboxylase; IGRP, islet-specific glucose-6-phosphate catalytic subunit-related protein; MHC, major histocompatibility complex; NOD, nonobese diabetic; T1D, type 1 diabetes.

\section{Competing interests}

The authors declare that they have no competing interests.

\section{Acknowledgments}

Work in the authors' laboratory is supported by the Juvenile Diabetes Research Foundation (grants 1-2008555 and 17-2010-227).

\section{References}

I. Santamaria P: The long and winding road to understanding and conquering type I diabetes. Immunity 20I0, 32:437-45.

2. Todd JA: Etiology of type I diabetes. Immunity 20I0, 32:457-67.

3. Stadinski B, Kappler J, Eisenbarth GS: Molecular targeting of islet autoantigens. Immunity 20I0, 32:446-56.

4. Stadinski BD, Delong $T$, Reisdorph N, Reisdorph R, Powell RL, Armstrong M, Piganelli JD, Barbour G, Bradley B, Crawford F, Marrack P, Mahata SK, Kappler JW, Haskins K: Chromogranin A is an autoantigen in type I diabetes. Nat Immunol 2010, I I:225-3 I.

FI000 Factor 8.3 Exceptional

Evaluated by Peter Van Endert 17 Feb 2010, Matthias von Herrath 04 Mar 2010, Mark Anderson 12 Mar 2010, Andrea Sant 03 Jun 2010

5. Zhang L, Nakayama M, Eisenbarth GS: Insulin as an autoantigen in NOD/human diabetes. Curr Opin Immunol 2008, 20: I I -8.

6. French MB, Allison J, Cram DS, Thomas HE, Dempsey-Collier M, Silva A, Georgiou HM, Kay TW, Harrison LC, Lew AM: Transgenic expression of mouse proinsulin II prevents diabetes in nonobese diabetic mice. Diabetes 1997, 46:34-9.

7. Nakayama M, Abiru N, Moriyama H, Babaya N, Liu E, Miao D, Yu L, Wegmann DR, Hutton JC, Elliott JF, Eisenbarth GS: Prime role for an insulin epitope in the development of type I diabetes in NOD mice. Nature 2005, 435:220-3.

FI000 Factor 6.4 Must Read

Evaluated by Kai Wucherpfennig 19 May 2005, Peter Van Endert 19 May 2005

8. Jaeckel E, Klein L, Martin-Orozco N, von Boehmer H: Normal incidence of diabetes in NOD mice tolerant to glutamic acid decarboxylase. J Exp Med 2003, 197:1635-44.

FI000 Factor 4.8 Must Read

Evaluated by Matthias von Herrath 26 Jun 2003, Peter Van Endert 03 Jul 2003

9. Krishnamurthy B, Dudek NL, McKenzie MD, Purcell AW, Brooks AG, Gellert S, Colman PG, Harrison LC, Lew AM, Thomas HE, Kay TW: Responses against islet antigens in NOD mice are prevented by tolerance to proinsulin but not IGRP. J Clin Invest 2006, I 1 6:3258-65

FI000 Factor 4.9 Must Read

Evaluated by Luciano Adorini I5 Dec 2006, Grant Morahan I5 Dec 2006, Matthias von Herrath 08 Jan 2007

10. Hassainya $Y$, Garcia-Pons F, Kratzer R, Lindo V, Greer F, Lemonnier FA, Niedermann G, van Endert PM: Identification of naturally processed HLA-A2-restricted proinsulin epitopes by reverse immunology. Diabetes 2005, 54:2053-9.

II. Standifer NE, Ouyang Q, Panagiotopoulos C, Verchere CB, Tan R, Greenbaum C], Pihoker C, Nepom GT: Identification of Novel HLA-A*020I-restricted epitopes in recent-onset type I diabetic subjects and antibody-positive relatives. Diabetes 2006, 55:306I-7.

FI000 Factor 3.0 Recommended

Evaluated by Bart Roep 07 Nov 2006

12. Mallone R, Martinuzzi E, Blancou P, Novelli G, Afonso G, Dolz M, Bruno G, Chaillous L, Chatenoud L, Bach JM, van Endert P: CD8+ $T$-cell responses identify beta-cell autoimmunity in human type I diabetes. Diabetes 2007, 56:6I3-2I.

13. Martinuzzi E, Novelli G, Scotto M, Blancou P, Bach JM, Chaillous L, Bruno $G$, Chatenoud $L$, van Endert $P$, Mallone $R$ : The frequency and immunodominance of islet-specific CD8+ T-cell responses change after type I diabetes diagnosis and treatment. Diabetes 2008, 57:|3|2-20.

14. Skowera A, Ellis RJ, Varela-Calviño R, Arif S, Huang GC, VanKrinks C, Zaremba A, Rackham C, Allen JS, Tree TI, Zhao M, Dayan CM, Sewell AK, Unger WW, Drijfhout JW, Ossendorp F, Roep BO, Peakman M: CTLs are targeted to kill beta cells in patients with type I diabetes through recognition of a glucose-regulated preproinsulin epitope. J Clin Invest 2008, i I 8:3390-402.

15. Toma A, Laïka T, Haddouk S, Luce S, Briand JP, Camoin L, Connan F, Lambert M, Caillat-Zucman S, Carel JC, Muller S, Choppin J, Lemonnier F, Boitard C: Recognition of human proinsulin leader sequence by class I-restricted T-cells in HLA-A*020I transgenic mice and in human type I diabetes. Diabetes 2009, 58:394-402.

16. Herold KC, Brooks-Worrell B, Palmer J, Dosch HM, Peakman M, Gottlieb P, Reijonen H, Arif S, Spain LM, Thompson C, Lachin JM: Validity and reproducibility of measurement of islet autoreactivity by $T$-cell assays in subjects with early type I diabetes. Diabetes 2009, 58:2588-95.

17. He XL, Radu C, Sidney J, Sette A, Ward ES, Garcia KC: Structural snapshot of aberrant antigen presentation linked to 
autoimmunity: the immunodominant epitope of MBP complexed with I-Au. Immunity 2002, I 7:83-94.

FI000 Factor 3.0 Recommended

Evaluated by Peter Jensen 21 Aug 2002

18. Mohan JF, Levisetti MG, Calderon B, Herzog JW, Petzold SJ, Unanue ER: Unique autoreactive $T$ cells recognize insulin peptides generated within the islets of Langerhans in autoimmune diabetes. Nat Immunol 2010, I I:350-4.

FI000 Factor 4.9 Must Read

Evaluated by Matthias von Herrath 05 Mar 2010, Grant Morahan 23 Mar 2010, Peter Van Endert I4 May 2010

19. Brosi H, Reiser M, Rajasalu T, Spyrantis A, Oswald F, Boehm BO, Schirmbeck R: Processing in the endoplasmic reticulum generates an epitope on the insulin A chain that stimulates diabetogenic CD8 T cell responses. J Immunol 2009, I83: 7187-95.

FI000 Factor 6.0 Must Read

Evaluated by Peter Van Endert 0 I Dec 2009

20. Chatenoud L, Bluestone JA: CD3-specific antibodies: a portal to the treatment of autoimmunity. Nat Rev Immunol 2007, 7:622-32.

21. Keymeulen B, Vandemeulebroucke E, Ziegler AG, Mathieu C, Kaufman L, Hale G, Gorus F, Goldman M, Walter M, Candon S, Schandene L, Crenier L, De Block C, Seigneurin JM, De Pauw P, Pierard D, Weets I, Rebello P, Bird P, Berrie E, Frewin M,
Waldmann H, Bach JF, Pipeleers D, Chatenoud L: Insulin needs after CD3-antibody therapy in new-onset type I diabetes. N Engl J Med 2005, 352:2598-608.

FI000 Factor 6.5 Must Read

Evaluated by Mark Atkinson 06 Jul 2005, Kai Wucherpfennig 08 Aug 2005, Marie Kosco-Vilbois 05 Oct 2005

22. Shoda LK, Young DL, Ramanujan S, Whiting CC, Atkinson MA, Bluestone JA, Eisenbarth GS, Mathis D, Rossini AA, Campbell SE, Kahn R, Kreuwel HT: A comprehensive review of interventions in the NOD mouse and implications for translation. Immunity 2005, 23: II5-26.

23. Ludvigsson J, Faresjö $M$, Hjorth $M$, Axelsson S, Chéramy $M$, Pihl $M$, Vaarala O, Forsander G, Ivarsson S, Johansson C, Lindh A, Nilsson NO, Aman J, Ortqvist E, Zerhouni P, Casas R: GAD treatment and insulin secretion in recent-onset type I diabetes. $N$ Engl J Med 2008, 359:1909-20.

FI000 Factor 3.0 Recommended

Evaluated by Carla Greenbaum 19 Jun 2009

24. Tsai S, Shameli A, Yamanouchi J, Clemente-Casares X, Wang J, Serra P, Yang Y, Medarova Z, Moore A, Santamaria P: Reversal of autoimmunity by boosting memory-like autoregulatory $T$ cells. Immunity 2010, 32:568-80.

FI000 Factor 9.9 Exceptional

Evaluated by E Charles Snow 28 Apr 2010, Peter Van Endert 14 May 2010, Thomas Kay 08 Jun 2010 